\title{
Pliny's Natural History: a medium for preservation and a cause of loss of knowledge
}

\author{
JACOB ISAGER \\ Syddansk Universitet, Odense \\ Denmark
}

\begin{abstract}
Resumo. A História Natural de Plínio: meio de conservação e causa de perda de conhecimento. A História Natural de Plínio pretende ser um inventário do mundo conhecido para os romanos. Este artigo discute, na sua primeira parte, as razões desse projeto. Foi um enorme trabalho coletar e organizar o material, e como exemplo de metodologia, escolhi os capítulos de arte grega e romana (ou arte greco-romana) que tiveram grande impacto nas posteriores histórias da arte. Uma análise da exposição de Plínio sobre a história da arte romana e grega revela que ele tinha diferentes motivos para estabelecer essas histórias da arte. O que liga as duas partes como uma uma unidade é o impacto das peças de arte grega e romana no espaço urbano de Roma. Templos e outros prédios públicos funcionavam como galerias de arte, com variadas coleções de obras-primas da arte grega, com isso elevando Roma à posição de grande centro do mundo. Assim como as coleções de estátuas, a História Natural de Plínio, com sua coleção de memórias do Império Romano, preserva conhecimento esquecido. Tornou-se um monumento ao conhecimento do mundo inteiro e foi transmitido a nós em sua totalidade.
\end{abstract}

PALAVRAS-CHAVE. História Natural; preservação do conhecimento; história da arte grega; históia da arte romana; arte greco-romana; memória e monumentos.

\section{The Natural History}

Pliny's Natural History was a very ambitious project. It was meant to be a inventory of the whole world known to the Romans, that is, an inventory of the Roman Empire. The result of this project was what today is generally accepted as the earliest encyclopedia to have survived.

Pliny declares his ambitions for this grand project in his Preface to his encyclopedia which is divided into 37 books. The whole work was dedicated to Titus, son and co-emperor of Vespasian and is to be dated around $78 \mathrm{AD}$. Pliny characterizes his enterprise as something completely new on Roman soil. It is adressed to the Roman people, the Quirites, and the ideal readers are said to be the peasants and the artisans, the ideal Romans of the good old days. And, Pliny adds, it is also also adressed to those who have time to 
spare for studies, a group that may seem more realistic readers. The gentleman farmers more than the ordinary peasants. Pliny's references to Cato and Vergil confirm this attitude.

In his modesty Pliny contradicts the actual content of his work when in the Preface he presents his writings as being of a fairly light nature, permitting neither digressions nor discourses on wondrous events (casus mirabiles). He declares his subject a barren one - sterilis materia, before revealing his subject which he then states as rerum natura, hoc est vita, an exposition of Nature itself, of life itself - an overwhelming theme which certainly cannot be defined as a barren subject. Continuing with less modesty Pliny inserts his Natural History into the history of Greek and Roman literature, telling us that he follows a path that has never been traversed by other writers neither Roman nor Greek and nobody before him has on his own treated all aspects of this subject. Pliny may even be rigth when stating that nobody before him has had this ambition of totality. To achieve this, Pliny adds, he has to enter areas almost inaccessible and even if other authors may have treated it, it was still wrapped in shadowy darkness.

Pliny expressly says that he aims at treating everything that the Greeks designate as belonging to he enkyklios paideia, encyclopedic education as I would prefer to translate it here. He wants to include what has been unknown or considered unclear for comprehension. To quote himself (NH Praef. 15): res ardua uetustis nouitatem dare, nouis auctoritatem, obsoletis nitorem, obscuris lucem, fastiditis gratiam, dubiis fidem, omnibus uero naturam et naturae sua omnia. It is a difficult task to impart a sense of novelty to what is old, to give authenticity to what is new, to make the worn shine, to shrow light on darkness, to make the rejected significant, to make the doubtful credible, to give everything it proper nature and to give Nature all that is hers." According to Pliny this is the road he will follow in his encyclopedic project and in false modesty he draws a parallel to the ruling Emperors when he points out the position of the learned man, who through the conquest of difficulties (difficultatibus victis) prefers to be of assistance and use rather than to please and curry favour. A person who makes a contribution to the Roman people and not only to himself. Utilitas iuvandi, the idea of being of assistance and use for one's fellow man is a recurrent theme in the Natural History, most significantly expressed in Pliny's definition of the concept God in in his cosmology $(\mathrm{NH} 2,18)$ : Deus est mortali iuuare mortalem, et haec ad aeternam gloriam uia: hac proceres iere Romani, hac nunc caelesti passu cum liberis suis uadit maximus omnis aeui rector Vespasianus Augustus fessis rebus subueniens. That a mortal helps another mortal is God. And this is the way to eternal fame. The Roman leaders have followed this way and on it walks now with heavenward steps with his children the greatest regent 
of all time, Vespasianus Augustus, coming to relieve the needy world." The notions of helping and assisting, iuvare and subvenire, certainly reflects, from the author's level, his declared purpose with his Natural History, to collect a totality of knowledge of the known world and through organizing it in a written compendium to help and assist the Roman people to get this knowledge. A preréquisite for collecting this knowledge is the Pax Romana created by the Emperor.

In the preface Pliny further presents himself as a loyal servant of the Emperor, who dedicates all his time to his official duties and he speaks almost with the language of the civil servant making a report or inventory when he presents his Natural History as an account of tangible facts, res, to be kept in store rooms (thesauri) (NH Praef.17-18):

XX rerum dignarum cura (quoniam, ut ait Domitius Piso, thesauros oportet esse, non libros) lectione uoluminum circiter II, quorum pauca admodum studiosi attingunt propter secretum materiae, ex exquisitis auctoribus centum inclusimus XXXVI uoluminibus, adiectis rebus plurimis, quas aut ignorauerant priores aut postea inuenerat uita. Nec dubitamus multa esse quae et nos praeterierint. (18) Homines enim sumus et occupati officiis subsiciuisque temporibus ista curamus, id est nocturnis, ne quis uestrum putet his cessatum horis. Dies uobis impendimus, cum somno ualetudinem computamus, uel hoc solo praemio contenti, quod, dum ista, ut ait M.Varro, musinamur, pluribus horis uiuimus: profecto enim uita uigilia est.

"In 36 volumes I have collected 20.000 things worthy of mention - in fact it is true, as Domitius Piso says, that they ought to be stored safely in store rooms and not in books - the result of the reading of 2000 volumes, few of which have been touched by the learned because of the abstruseness of the subject matters, written on the basis of the study of hundreds of authors, and I have added many things that my predecessors either were ignorant of or which have been discovered later. Nor do I doubt that much has escaped my notice. For I am only human and preoccupied with my official duties (officia). The present work was carried out during my leisure hours to wit at night... To you I dedicate my days and only accord my health that sleep which it must have." The dutyful Pliny concludes these remarks with the famous saying (Praef.18): Profecto enim vita vigilia est. "Indeed, to be alive is to be awake."

Surely, some of Pliny's numbers must be taken with a pinch of salt. The total of 36 volumes can be verified. Book 1 contains only preface and indices to the next 36 books. The numbers 20.000 and 2000 thousands must seen a rhetorical exaggerations, numeri infiniti. Pliny's encyclopedic project 
is not organized with entries listed alphabetically as modern encyclopedias, but according Pliny's own classification of the world, as I shall come back to. Book 1 serves as an index to the Natural History and he lists the different topics. It is made, he says, to spare the user from reading through the work, to make it possible just to look up this and that. Pliny even lists his sources foreign and well as Roman. The authors mentioned in Book 1 add up to 473, 327 foreign and 146 Roman. Pliny clearly expresses his debt to former authors and underlines that one has to make it clear from whom one has benefitted. Other authors, even reliable ones from the present, he says, have been caught in copying verbatim from the old ones without acknowledgement of sources. It is truly an expression of a submissive attitude and unfortunate mental equipment to allow one self to be caught in theft rather than to repay one's debt (Praef. 21-23).

In fact, Pliny seems to us the only known author from antiquity who systematically acknowledges his sources. Additionally he often refers to his source in the text itself. How far and how close he followed his sources we cannot check, because with a few exceptions, they do not exist today. $\mathrm{He}$ seems even to have mentioned some authors without using them, thus giving suggestions to his reader for further reading. For how long the readers were able to follow Pliny's suggestions, we do not know. Unfortunately it was Pliny's own work in which information from all those author were collected that became one main cause for the fate of these authors. Their works went into oblivion and they are lost today.

Thus, according to Pliny, one reason for him to enter this pioneering project was to help the Roman people to acquire universal knowledge of the known world, the Roman Empire.

He further tells us why he found that the time had come to create an inventory of the world to preserve the knowledge of his time.

In book 2 he provides an account of how the world is arranged and Man's relationship with Nature. His account bears the stamp of primarily the Stoic school. Scientist are praised for having been given a special insight into Nature, but they are not the masters of Nature. They do not look for order, but follow the material in its diversity. They are granted the knowledge that Nature wishes to grant them.This insight makes them helpers of mankind. In discussing the winds, a subject treated by more than 20 Greek authors, Pliny takes up an interesting discussion of what creates the best conditions for acquiring knowledge. He presents the following theory (NH 2,117-118):

Viginti amplius auctores Graeci ueteres prodidere de his obseruationes. Quo magis miror orbe discordi et in regna, hoc est in membra, diuiso tot uiris curae fuisse tam ardua inuentu, inter bella praesertim et in- 
fida hospitia, piratis etiam, omnium mortalium hostibus, transituros fama terrentibus, ut hodie quaedam in suo quisque tractu ex eorum commentariis, qui numquam eo accessere, uerius noscat quam indigenarum scientia, nunc uero pace tam festa, tam gaudente prouentu rerum artiumque principe, omnino addisci nova inquisitione, immo ne ueterum quidem inuenta perdisci. Non erant maiora praemia, in multos dispersae fortunae magnitudine, et ista plures sine praemio alio quam posteros iuuandi eruerunt. Namque mores hominum senuere, nec fructus, et inmensa multitudo aperto, quodcumque est, mari hospitalique litorum omnium adpulsu nauigat, sed lucri, non scientiae gratia. Nec reputat caeca mens et tantum auaritiae intenta id ipsum scientia posse tutius fieri.

"When the world was in discord and divided into many states, that is in limbs, a lot of people occupied themselves with difficult studies in spite of wars, faithless allies and the fact that pirates, the enemies of mankind, prevented the dissemination of views"... Contrasting this with his own time he proceeds: "Now when peace is stable and an emperor may take satisfaction in material and cultural progress, no new knowledge is added from new studies. Indeed even the old discoveries are no longer been studied properly". To this Pliny adds his moral indignation: "In the old days days... most of these people worked their way to their results without any other reward than that of helping posterity. Now, morality has lost its hold on men, but the quest for profit has not. Now that the sea is open, all coasts hospitable, great crowds set sail — not in order to gain knowledge but for profit. In their blindness and greed they fail to see that profit can be obtained more safely through knowledge" (NH 2,117-118).

So, according to Pliny the days of discovery are over. They were made under the conditions of war when the world was split up in small countries. In time of peace, there seems to be no need to gain new insights or expand on experience. Peace and the uniting of the world into one Empire have brought all development to a stand-still. But the Imperium Romanum and the Pax Romana are not to blame nor the Flavians who have brought prosperity and even improved the conditions for progress. But people have neglected these possibilities or abused them for their greed, which, as Pliny adds with a touch of irony, would be even better satisfied through greater knowledge.

To sum up Pliny's conclusion: The knowledge of the world has reached an optimum and the feeling of need for new discoveries and experience has come to a stand-still. To prevent that this total of old and more recent knowledge shall be lost for mankind Pliny's sees it as his task to collect and correct this knowledge into an encylopedia. War time and discord creates new knowledge. Times of peace and prosperity creates the background for col- 
lection of and thereby preservation of knowledge, only. Science has reached its limits and discoveries have given way to compilations. That is Pliny's main thesis. Studies of encyclopedias seem to confirm that the emergence of encyclopedias is connected with a cyclic process of the acquirement of new knowledge. When this cyclic process comes to a point showing a stagnation of knowledge, caused by the feeling that there are no more possibilities for progress, then the time is ripe for encyclopedias. The First Century AD seems to represent a period of stagnation.

\section{Organization of the Natural History}

How, then did Pliny organize this totality of knowledge? Book 2 is a cosmology in which Pliny describes the world with the four elements as his point of departure. The rest of his work follows another classification: The animal world and the plant world - two living worlds, and the mineral world, the inért world. There are books treating Geography, Antropology, and Zoology, a botanical handbook mostly about trees, arbores. Then follow books about medical uses of botanical and animal substances. The last 4 books cover Mineralogy and metallurgy, metalla. Man has a superior role as the master of the three kingdoms. Mineralogy constitutes the last part but not the least important, as Pliny when treating gold, silver, copper and marble takes the opportunity to point out Man's abilities as craftsman or artist, as artifex. The classification is not what we would expect by modern standards. The metal and stones are treated according to their significance in art and architecture and from a medical point of view. Medicine is a most important gift of Nature never to be forgotten.

\section{The archaeology of the Encyclopedia}

In his recent book on Pliny the Elder's Natural History with the subtitle The Empire in the Encyclopedia the author Trevor Murphy imagines (p.1-2) a situation in which we have to reconstruct a lost civilization only on basis of their encyclopedias and when we have specially educated archaeologists of refence books to reconstruct this lost civilization.They would need two skills: inductive reasoning so as to build up a society on basis of the specific terms in the lists. The other most necessary skill would be that of looking at the principles on which the encyclopedia is constructed and deduce what does not appear in any list: the logic of that culture. The principle of classifying, grouping and making sequences of information, distinguishing the necessary from the supplementary, discloses how the encyclopedia made sense of the world. 
As already said Pliny's encyclopedic work caused the almost total loss of all the authors he quotes and refers to. We have today only his way of seeing the world as basis for our reconstruction. If we want to restore the contents of the lost works we can make make Quellenuntersuchungen, as it has been done, and try to establish the identity of the lost sources, but we have to go through Pliny and in many cases it takes us only a little further. It remains a hermeneutical circulus vitiosus.

\section{The Chapters on Art}

As an example I will try to make an excavation of the Chapters on art found in the mineralogy of Pliny's Natural History and try to establish a stratigraphy that may help us in a search to sort out which are the informations we were intended to have and which were lost in the process.

Pliny's chapters on art are found as said already in the the exposition of the mineral world seemingly as digressions. To many modern readers, not to mention archaeologists and art historians, this important theme is treated most casually and unsatisfactory. But seen in a context of the Natural History, where Pliny focusses on Man's abilities to exploit the resources made available by Nature herself, Pliny's treatment may seen more logic.

A main scope for the Natural History is to deliver knowledge and to correct wrong opinions and this is Pliny's declared reason for taking up the topic of art in bronze when treating copper in Book 34. He has, in fact, treated gold and silver in the preceeding book thus following a hierarchy of metals. Copper is a prerequisite for bronze and he starts by documenting the use of bronze in early Rome by pointing out combinations with the word bronze, aes in the Latin language. The signifiers demonstrate the existence of the signified. Pliny proceeds with different bronze alloys discussing the old days when the artistic reprensentation, ars, was more important than the material, materia, thereby expressing his moral indignation with his own time. This brings him to a controversial theme: Corinthian bronze and the many misunderstandings connected with this alloy. To correct among other things the dating of the invention of Corinthian bronze alloy Pliny gives his readers a list of the famous Greeks sculptors placed chronologically in Olympiac years which can easily be converted into Roman chronology. But before that Pliny gives an exposition of some bronze workshops in Greece and the use of bronze in furniture, instrumenta domestica, in architecture and for statues in Rome. Focussing on the use of bronze in Roman society Pliny gives us rather a social history of Roman Art than a stylistical and chronological account of the development of Roman art. Its becomes clear when we look at the headings for these chapters given by Pliny in his index: 
The first bronze statue of a god in Rome. Types and forms of honorific statues- with examples: Statues of people wearing togas. Statues on columns. Public statues of foreigners, statues of women. Equestrian statues. Honorific arches. Other themes are: Removal of statues. Who erected the statues. Excessive prices of statues. Colossal statues. A more nationalistic aspect is found when he tries to find early examples of bronze artists in Italy. There is almost no concern about the artists behind the art works. Roman art and architecture is presented mostly as anonymous.

When Pliny tells us about colossal statues, he gives as heading for this section daring, audacia, and it brings him rather unexpectedly into another highly interesting theme about artistic value, which the modern reader would have wanted him to expand on in a Roman context: that is verisimilitudo, deceptive likeness, that is realism in art. The statue of a dog licking his wounds, mentioned by Pliny as an example of incredible realism could be a work of Lysippos. And this is the catchword for Pliny to switch from a Roman to a Greek context and give the promised lists of Greek artists in the field of bronze, originally set in the text to put Corinthian bronze in a chronological context. Pliny delivers first a chronological list of the most famous Greek sculptors from the 83rd Olympiad to the $156^{\text {th }} \mathrm{Ol}$. That is from 448-153 BC. He surprises us with the much discussed statement that the art of bronze sculpture died out after 293 BC and was revived in $156 \mathrm{BC}$. We are informed about who were contemporaries and competitors and who were pupils of whom. We have to wait for the next list, still treating only the most famous artist to find information about the best known works, the places to find them and each artist's contributions the development of art. Pliny confines himself to a sequence from Phidias in the mid 5.century to Lysippos in the late $4^{\text {th }}$ century $\mathrm{BC}$, the evolution from idealism to realism. This list is followed by a list of lesser known artists, with reference to at least one work of each and it is spiced with anecdotes. The names on this list are given alphabetically according to the Roman alphabet, whereas the next short list of artist of more humble talents are listed according to the Greek alphabet. Finally another alphabetical list gives us the names of those who worked in the same genres: making statues of philosophers, wrestlers, old women etc.

We find the same mixture in Pliny's chapters on Greek and Roman painting. An evolutionary exposition mentioning various artist's contribution to the development of Greek painting towards verisimilitudo, realism and alphabetical lists of names and the topic of their main works. Entertaining anecdotes are added. Very few Roman artist are mentioned by name. But two for us most important discussions on Roman portraits and Roman triumphal painting are found there. 
If we want to establish an account and an evaluation of the the information given by Pliny on Greek art we reach the following result: Pliny's lists are the most complete existing today. He lists many names of artists not known to us from other literary or archaeological sources. The names of artists known from other ancient texts are almost all found in Pliny as well among those pronounced by him to be the most famous. That means that Pliny's preferences agree with those of other Greek and Roman authors. Pliny informs us of his sources which include Greek and Roman authors, so we can conclude that Pliny excerpts, loans or inspiration from the now lost sources, as far as we can deduce, agree with the selections made by the preserved Greek and Roman authors. Thus, we can be rather confident that Pliny's choice of the now lost authors represented a canon of authors known by the literary elite in Greece and Rome. How far Pliny used Greek authors directly or through Roman authors as Varro, is rather difficult to say even if he now and then quotes his source by name.

Pliny's exposition of a theory of evolution in Greek sculpture and painting reflects a Greek tradition for explaining the history of artes, technai and genres as a series of developmental stages and several allusions to this tradition are found among others in Cicero and Quintilian. But here again Pliny stands as the main transmitter of this lost art historical literature, which through Pliny has had the well known impact on art theoretical models in the Renaissance and in the 18th century with Winckelmann.

More generally Pliny gives us the almost sole surviving exposition on Greek art and it is interesting to study how his chapters on art has been received and used in modern archaeology. He remains the main source for the history of Greek sculpture and painting. He delivers long lists of Greek artist and their works often very loosely described. As Pliny seems to give a canon of famous artists, this has tempted many to combine existing nameless statues with names given by Pliny, and thereby to give a much higher status and popularity to otherwise anonymous art objects. In every museum which exhibits Greek and Roman art one can find labels with the text: Roman copy of a Greek original ascribed to this or that artist, mentioned by Pliny. The statues will most often be Roman copies or adaptations and since the possible Greek original is lost we cannot verify the relationship between the copy and the original. The possible original is out of reach for comparacy as are the sources for Pliny's art chapters. It has been said about Roman art that until recently Roman art was not looked at, but looked through to get information of the Greek originals behind. The same can be said of Pliny's art chapters.

In fact, they give most important knowledge of Roman art and the Roman attitude to art. They reveal Pliny's nationalism when viewing art and 
his more political intentions. This constitute what we may consider his own main contribution when it comes to organizing his immense art historical material. I have already pointed out his social approach in his treatment of bronze in Rome.

At the conclusion of his registration of Greek artist and works of art in bronze Pliny makes the following statement $(\mathrm{NH} \mathrm{34,} \mathrm{84):} \mathrm{atque} \mathrm{ex} \mathrm{omni-}$ bus quae rettuli clarissima quaeque in urbe iam sunt dicata a Vespasiano principe in templo Pacis aliisque eius operibus, uiolentia Neronis in urbem conuecta et in sellariis domus aureae disposita. "Of all the works that I have enumerated the most famous are found in Rome today, dedicated by the Emperor Vespasian in the Templum Pacis and in his other buildings. They were brought to Rome by Nero as plunder and were displayed throughout the private rooms of the Domus Aurea."

Here Pliny views the works of art in a new context, in that of politics. Great art should be exhibited publicly and not be hidden away for the few as in the exemple of Nero whom Pliny often sets as a contrast to Vespasian. The way of looking at Greek Art history as a sequence of masterpieces that ought to be set on display in Rome is found in Pliny's chapters in book 36 on marble. Here he refrains from developmental schemes or long list of artist - they may overlap those on bronze. Instead he describes the Greek marble sculpture through their representation in Rome. He proceeds in the same book with a short presentation of the wonders of the world. And he contrasts those with a long list of the architectural wonders of Rome. And most famous of all are two triumphal building, the Forum made by Augustus and the Temple of Peace erected by Vespasian after the Jewish war. We told that in both places the finest pieces of Greek art were put on exhibition.

Here Pliny offers his reader a new way of organizing and presenting the material. Rome is seen as a museum of great art pieces from the whole world, mostly the eastern Mediterranean world, the world conquered by the Romans. Pliny expresses it so (NH 36.101),

Verum et ad urbis nostrae miracula transire conueniat DCCCque annorum dociles scrutari uires et sic quoque terrarum orbem uictum ostendere. Quod accidisse totiens paene, quot referentur miracula, apparebit; uniuersitate uero aceruata et in quendam unum cumulum coiecta non alia magnitudo exurget quam si mundus alius quidam in uno loco narretur.

that "the wonders of Rome, and Rome's will to learn demonstrate that also in this way the world has been conquered. It has happened in as many cases as it is possible to point out wonders in Rome. If those wonders are heaped in one pile, this assemblage would tower as a pinnacle as if some other 
world gathered in one place were described." The art works are gathered in Rome as a result of the conquest of the Roman Empire, Rome has become a museum of the world or rather Rome has become one unique triumphal monument. A monumentum which has collected memories, memoriae, of the whole conquered world.

Maybe, Pliny would expect his readers to draw a parallel to his own Natural History: Pliny's endeavours to preserve knowledge from oblivion have made his collection of memories from the Roman Empire, a memorial, a monumentum of knowledge of the whole world.

Pliny's Natural History, a unique thesaurus of ancient knowledge has been preserved to us intact in 37 volumes despite the fact that the Natural History was excerpted and abbreviated from late antiquity through the Middle Ages. Pliny did not share the fate of for example Livy where abbreviations have substituted an important part of his work. Pliny has been transmitted in its totality as well as and in excerpts. And he kepts its popularity in the Renaissance. The editio princeps was published in 1469 and before 1500 fifteen different editions came out. In the 16 century, 89 new editions saw the light of the day. That is an average of almost one per year, and the next centuries saw a constant flow of new editions and translations.

Pliny's Natural History may have caused loss of ancient authors, but the amount of knowledge it has preserved certainly has had far reaching effects.

Abstract. Pliny's Natural history is meant to be an inventory of the world known to the Romans. This article discusses in its first part Pliny's reasons for entering on this project. It was an enormous task to collect and organize the material and as an example of his working methods I have chosen his chapters on Greek and Roman art, which have had great impact on later histories of art. An analysis of Pliny's exposition of the history of Roman and Greek art reveals that Pliny have different motives for establishing these art histories. What binds the two parts together as a unity is the impact of Greek and Roman art pieces on the cityscape of Rome. Temples and other public building functioned as art galleries with varied collections of the masterpieces of Greek art, thereby elevating Rome's status as master and centre of the world. Like the collections of statues Pliny's Natural History with its collection of memories from the Roman Empire preserves knowledge from oblivion. It becomes a monumentum of knowledge of the whole world and it has been transmitted to us in its totality.

KEYWORDS. Natural History; preservation of knowledge; Greek Art history; Roman Art history; Greco-Roman Art; memory and monuments. 